\title{
Research Progress on the Impact of Wind Farms on Regional and Global Climate
}

\author{
GONG Huanzhang ${ }^{1, a}$, BAO Zhe ${ }^{1, b}$, LI Wei ${ }^{1, c}$ \\ ${ }^{1}$ Key Laboratory of Regional Energy System Optimization, Ministry of Education, North China \\ Electric Power University, Beijing, 102206, China \\ agonghuanzhang54@gmail.com, b125274222@qq.com, '925657837@qq.com
}

\begin{abstract}
Keywords: Wind farms; Regional; Global; Climate
Abstract. The influence of wind energy on the energy cycle and atmospheric circulation in nature and the possible impact on the climate are the hotspots in recent years. The comprehensive analysis of domestic and foreign research shows that the wind farms have a certain impact on regional and global precipitation, temperature, humidity, evaporation, wind speed and other climatic factors, but the conclusions varies from different methods and theoretical. Because of the limitation of the existing observations, simulation results of climate models also have many uncertainties, researchers should continuously improve the observation method and the optimization of climate model, improve the relevant theory, so as to obtain more accurate conclusions.
\end{abstract}

\section{Introduction}

Wind power is a new clean and renewable energy, has the advantages of great potential for development, mature technology and large-scale development, etc. The demand for low-carbon energy greatly promoted countries to build large-scale wind farms in the inland and coastal areas containing rich wind energy resources. According to the Global Wind Energy Council, wind power was predicted to meet $20 \%$ of the global electricity demand by 2030 [1]. With the smooth development of China's "13th Five-Year Plan", renewable energy has developed rapidly and the energy structure has been optimized. As the largest new energy power generation mode, the development of wind power has become an important part of promoting China's energy transformation. Although wind power produces virtually no air and water pollution, a great deal of work have been taken to explore the impact on climate caused by wind farms, this paper will elaborate the research results from four perspectives: field observation, remote sensing technology, regional and global model.

\section{Study on the Influence of Wind Farm by Field observation}

It is an important means to study the climate change of the wind farm by observing the area of the surrounding area of the wind farm and obtaining the most direct meteorological data, through which could visually display the meteorological changes of the studied area.

Frandsen et al. [2] calculated the meteorological observation data of the Danish wind farm, accordingly pointed out that the wind speed of the downwind winds decreased significantly from the wind direction, and the wind speed gradually recovered from $8 \mathrm{~km}$ downwards, moreover, only $90 \%$ of the original wind speed was restored at $11 \mathrm{~km}$. By observing the Midwest wind farm in America, Smith et al. [3] found that: in the blade sweep area and the fan axle height, wind speed was significantly reduced together with the significant enhancement of turbulence intensity, and these phenomena were more remarkable at night. Roy et al. [4] studied the effects of wind farms on temperature by reference to the observations of the wind farm from June to August in 1989 in San Gorgonio, get the following law: wind farms play a role of cooling in the daytime, on the contrary has an effect of warming during the night. The trend is shown in the following fig1. 


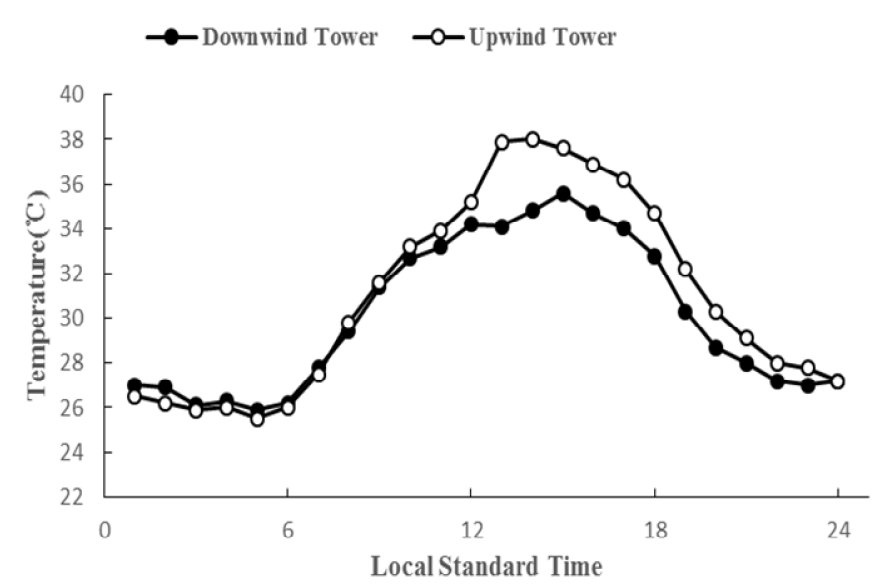

Fig.1 Diurnal variation of near surface air temperature averaged over June-August of 1989

Field observation has also been carried out in China. With the help of HOBO automatic weather station, $\mathrm{Xu}$ [5] carried out field observation on the field of wind power in Inner Mongolia, and obtained the relevant meteorological data of the local area below $3 \mathrm{~m}$. The data reveal that: the wind speed has a tendency to decrease due to the effect of turbine; the interior zone of wind farm showed a trend of warming and humidity reduction; the daily evapotranspiration below a single turbine is obviously higher than that of the surrounding area, reaching $8.6 \mathrm{~mm}$.

According to the existing observation results at home and abroad, it can be concluded that wind farm operation will result in wind speed reduction, evapotranspiration change, temperature change, humidity reduction, turbulence intensity enhancement and so on. However, field observations usually last only a few months, could not well reflect the changes in climate, and due to the limitations of observation technology, part of the research data remained to be verified.

\section{Study on the Influence of Wind Farm by Remote Sensing Technology}

Remote sensing technology avoids the shortcomings of field observation, such as short test cycle, imperfect data, and the limited observation range. Nowadays, it is a research hotspots to study the wind farms by remote sensing technology.

Li et al. [6] combined with the meteorological data of Xilinhot city in Inner Mongolia and the remote sensing data from the US Earth Dynamics Simulation Team, compared the changes in the first eight years and the last six years of large-scale wind farms, and used the linear trend slope method in analyzing. The results showed that the wind farm will accelerate the evapotranspiration in the surface area, the increment speed is $141.05 \mathrm{~mm} /$ year, and the influence distance is more than $50 \mathrm{~km}$.

In order to study the effects of wind farms on the wind speed, Christiansen et al. [7] using satellites carrying synthetic aperture radar (SAR) to observe two large wind farms. The data showed that, under the action of wind farm, the wind speed averagely decreased by $8 \%-9 \%$, and after $5-20 \mathrm{~km}$, the wind speed recovery value is no more than $2 \%$.

In the field of remote sensing of the local temperature of the wind farm, a lot of work have been done at home and abroad, the related research results are shown in Table1. 
Table1 Study on the Effect of Wind Farm on Surface Temperature by Remote Sensing Technology

\begin{tabular}{|c|c|c|c|}
\hline Researcher & Research area & $\begin{array}{l}\text { Monitoring } \\
\text { time }\end{array}$ & Main conclusions \\
\hline Zhou et al [8] & $\begin{array}{l}\text { Large wind farm } \\
\text { in the Midwest } \\
\text { of Texas }\end{array}$ & $2003-2011$ & $\begin{array}{l}\text { The wind farm has a significant warming effect } \\
\text { on the surface, the increase rate could reach } \\
\qquad 0.72^{\circ} \mathrm{C} \text { per decade. }\end{array}$ \\
\hline $\begin{array}{l}\text { Walsh-Thomas } \\
\text { et al [9] }\end{array}$ & $\begin{array}{l}\text { San Gorgonio } \\
\text { Pass Wind Farm }\end{array}$ & 1984-2011 & $\begin{array}{l}\text { Supported by ArcGIS software, a warming trend } \\
\text { is consistently observed downwind of the wind } \\
\text { farm. }\end{array}$ \\
\hline Zhou et al [10] & $\begin{array}{l}\text { Large wind farm } \\
\text { in Texas }\end{array}$ & 2003-2011 & $\begin{array}{l}\text { The nocturnal atmospheric boundary layer is } \\
\text { usually more stable and thin in the nighttime, } \\
\text { produce a stronger warming effect; wind speed } \\
\text { is much high in summer, thus the turbine } \\
\text { generate more turbulence, and leading to a } \\
\text { stronger warming effect. }\end{array}$ \\
\hline $\begin{array}{c}\text { Chang et al } \\
\text { [11] }\end{array}$ & $\begin{array}{l}\text { Large wind } \\
\text { farms in } \\
\text { Guazhou China }\end{array}$ & 2005-2012 & $\begin{array}{l}\text { The increment speed of temperature is most } \\
\text { significant in summer, reaching } 0.51^{\circ} \mathrm{C} / 8 \text { years, } \\
\text { followed } 0.48^{\circ} \mathrm{C} / 8 \text { years in autumn, and } \\
0.38^{\circ} \mathrm{C} / 8 \text { years in winter, no obvious warming } \\
\text { trend observed in spring. }\end{array}$ \\
\hline
\end{tabular}

With the help of remote sensing observation, we get more detailed and accurate meteorological data, further verify that the wind farm will have an impact on temperature, evapotranspiration and wind speed, what's more, the variation trend and regularity of regional temperature in different times of the day and seasons are deeply studied.

\section{Study on the Influence of Wind Farm by Regional Climate Model}

It is a simple and efficient means to study climate change by parameterizing the relevant physical processes of complex climate systems [12] and abstracting them into a climate model based on certain logical relationship abstractions. Thus, the regional climate model is provided as an important technical method to study the climate impact of wind farm operation.

Roy et al. [13] used a new parametric approach based on the RAMS model to explore the meteorological effects of large-scale wind farms located in the Great Plains region in the summer. The simulation results show that the wind farm will significantly reduce the wind speed of the fan axle, and resulted by the turbulence generated by the fan rotor, bringing an effect of warming and humidity reducing, especially in the morning. Vautard et al. [14] set the EU regional wind power installed capacity reached the planned level in 2020 , the data fluctuating only during the winter season, and the temperature change is merely between $\pm 0.3{ }^{\circ} \mathrm{C}$, the change in precipitation only within $5 \%$, which were smaller than the natural interannual variation of the climate.

To study the effects of wind farm operation on wind speed, Frandsen et al. [2] developed a variety of mesoscale climate models, the results are shown in Table 2

Table2 Model name and its simulation results

\begin{tabular}{|c|c|c|}
\hline Model name & variable & Simulation results \\
\hline WAsP model & $\begin{array}{l}\text { surface } \\
\text { roughness }\end{array}$ & $\begin{array}{l}\text { The influence distance of wind farms on the wind speed is at } \\
\text { least } 10 \mathrm{~km}\end{array}$ \\
\hline Canopy Flow model & $\begin{array}{l}\text { volume } \\
\text { resistance }\end{array}$ & $\begin{array}{l}\text { The characteristic drag length of wind farm is estimated to be } \\
\qquad 15600 \mathrm{~m}\end{array}$ \\
\hline KAMM model & $\begin{array}{l}\text { surface } \\
\text { roughness }\end{array}$ & $\begin{array}{l}\text { Recovery to flow speed upwind of the wind farm takes } \\
\text { approximately } 30-60 \mathrm{~km} \text {. }\end{array}$ \\
\hline
\end{tabular}

According to the scholars from home and abroad, the wind farm has some influence on the regional temperature, humidity, precipitation and wind speed. However, the change trend and degree varies by 
different regions and different models.

\section{Study on the Impact of Wind Farms by Global Climate Model}

With the large-scale construction of wind farms on a global scale, the resulting climate impact will no longer be limited to a certain region, thus it is of great significance to use the global climate model to simulate the wind field in the vast inland and coastal areas.

By dint of climate model CAM3.5, Marvel et al. [15] predicted that near-surface wind energy can be mined at least 428TW and the wind energy available at the atmosphere is up to 1873TW. In view of the great amount of wind energy storage, many scholars consider that the construction of wind farms has no significant impact on the global climate, the relevant conclusion is summarized in following table3.

Table3 Study on the Effect of Wind Farm by Global Climate Model

\begin{tabular}{|c|c|c|}
\hline Researcher & $\begin{array}{c}\text { Model } \\
\text { name }\end{array}$ & Simulation results \\
\hline $\begin{array}{l}\text { Keith et al. } \\
\quad[16]\end{array}$ & $\begin{array}{l}\text { NCAR and } \\
\text { GFDL }\end{array}$ & $\begin{array}{c}\text { The maximum regional temperature changes up to } \pm 2^{\circ} \mathrm{C} \text {, but the global average } \\
\text { surface temperature changes can be ignored. }\end{array}$ \\
\hline & CAM3.5 & $\begin{array}{l}\text { Under the assumption of current global energy demand (about } 18 \mathrm{TW} \text { ), wind energy } \\
\text { development has no virtual impact on the global climate }\end{array}$ \\
\hline $\begin{array}{l}\text { Fitch } \\
{[18,19]}\end{array}$ & CAM5 & $\begin{array}{l}\text { Setting wind power installed capacity to meet } 16 \%, 65 \% \text { and } 130 \% \text { of the global } \\
\text { power plan in } 2050 \text {, the maximum global average temperature corresponding to } 60 \\
\text { years are }-0.013 \pm 0.015 \mathrm{~K}, 0.5 \mathrm{~K}, 0.7 \mathrm{~K} \text { respectively; the impact on wind speed is } \\
\text { mainly concentrated in the wind farm range, the maximum reduction is } 1.3 \mathrm{~m} / \mathrm{s} \text {, wind } \\
\text { farms outside the wind speed changes less than } 0.4 \mathrm{~m} / \mathrm{s} \text {; global precipitation changes } \\
\text { less than } 0.1 \% .\end{array}$ \\
\hline
\end{tabular}

However, some scholars believe that the role of wind farms on the global climate effect is more significant. With the aid of the three-dimensional climate model, Wang et al. [20] assumed the wind energy account for more than $10 \%$ of global energy in 2100 , the simulation results of onshore wind farm show that there are more than 1 degrees of temperature increase in many regions of the world, the trend of coastal wind farm is just the opposite. In virtue of the atmospheric circulation model (GCM), Barrie et al. [21] concluded that the operation of large-scale wind farms would change the surface roughness and promote the generation of cyclones, causing atmospheric disturbances, significantly affect the atmospheric circulation.

Considering that the time span of Wang's model is too large and Barrie did not rule out the impact from the North Atlantic whirlwind, so the simulation results itself contain a lot of uncertainty. Hence based on the results of most scholars, wind farms have little impact on global climate

\section{Conclusions}

Due to the different location of the wind farm and diversity of the model used as well as the parameters of the model, the conclusions of different scholars are varied, or even just opposite. Besides, many models are predictions of the future for a long time, the results exist a great deal of uncertainty. Future study should focus on enriching the climate observation data of wind farm; setting more precise model parameters and develop more sophisticated climate models to obtain particularly accurate and detailed research results, thus providing scientific basis for the rational location of wind farms, energy layout and relevant national major decisions.

\section{Acknowledgements}

This work was financially supported National Natural Fund Project (61471171) and the Special Funds for Fundamental Scientific Research Business Fees in Central Universities (2015ZZD08). 


\section{References}

[1] Council, Global Wind Energy. "Global wind energy outlook 2016." GWEC, November (2016).

[2] Frandsen, Sten T., et al. "The making of a second-generation wind farm efficiency model complex." Wind Energy 12.5 (2009): 445-458.

[3] Smith, Craig M., R. J. Barthelmie, and S. C. Pryor. "In situ observations of the influence of a large onshore wind farm on near-surface temperature, turbulence intensity and wind speed profiles." Environmental Research Letters 8.3 (2013): 034006.

[4] Roy, Somnath Baidya, and Justin J. Traiteur. "Impacts of wind farms on surface air temperatures." Proceedings of the National Academy of Sciences 107.42 (2010): 17899-17904.

[5] $\mathrm{Xu} \mathrm{R} \mathrm{H.} \mathrm{2014.} \mathrm{The} \mathrm{impact} \mathrm{of} \mathrm{wind} \mathrm{farm} \mathrm{on} \mathrm{local} \mathrm{micro} \mathrm{meteorological} \mathrm{environment} \mathrm{in} \mathrm{arid}$ region-taking Zhurihe Wind Farm as an example Hohhot, China: Inner Mongolia Agricultural University, 2014.(In Chinese)

[6] Li Guoqing, et al. "Analysis of the influence of wind farm on grassland evapotranspiration." Ecological Science 35.6 (2016): 146-151. (In Chinese)

[7] Christiansen, Merete Bruun, and Charlotte B. Hasager. "Wake effects of large offshore wind farms identified from satellite SAR." Remote Sensing of Environment 98.2 (2005): 251-268.

[8] Zhou, Liming, et al. "Impacts of wind farms on land surface temperature." Nature Climate Change 2.7 (2012): 539-543.

[9] Walsh-Thomas, Jenell M., et al. "Further evidence of impacts of large-scale wind farms on land surface temperature." Renewable and Sustainable Energy Reviews 16.8 (2012): 6432-6437.

[10]Zhou, Liming, et al. "Diurnal and seasonal variations of wind farm impacts on land surface temperature over western Texas." Climate dynamics 41.2 (2013): 307-326.

[11] Chang, Rui, Rong Zhu, and Peng Guo. "A Case Study of Land-Surface-Temperature Impact from Large-Scale Deployment of Wind Farms in China from Guazhou." Remote Sensing 8.10 (2016): 790.

[12]Fiedler, B. H., and A. S. Adams. "A subgrid parameterization for wind turbines in weather prediction models with an application to wind resource limits." Advances in Meteorology 2014 (2014).

[13] Baidya Roy, S., S. W. Pacala, and R. L. Walko. "Can large wind farms affect local meteorology?." Journal of Geophysical Research: Atmospheres 109.D19 (2004).

[14] Vautard, Robert, et al. "Regional climate model simulations indicate limited climatic impacts by operational and planned European wind farms." Nature communications 5 (2014).

[15] Marvel, Kate, Ben Kravitz, and Ken Caldeira. "Geophysical limits to global wind power." Nature Climate Change 3.2 (2013): 118-121.

[16] Keith, David W., et al. "The influence of large-scale wind power on global climate." Proceedings of the national academy of sciences of the United States of America 101.46 (2004): 16115-16120.

[17] Miller, Lee M., Fabian Gans, and Axel Kleidon. "Estimating maximum global land surface wind power extractability and associated climatic consequences." Earth Syst. Dynam 2.1 (2011): 1-12.

[18] Neale, Richard B., et al. "Description of the NCAR community atmosphere model (CAM 5.0)." NCAR Tech. Note NCAR/TN-486+ STR (2010). 
[19] Fitch, Anna C. "Climate impacts of large-scale wind farms as parameterized in a global climate model." Journal of Climate 28.15 (2015): 6160-6180.

[20] Wang, Chien, and Ronald G. Prinn. "Potential climatic impacts and reliability of very large-scale wind farms." Atmospheric Chemistry and Physics 10.4 (2010): 2053-2061.

[21] Barrie, D. B., and D. B. Kirk-Davidoff. "Weather response to a large wind turbine array." Atmospheric Chemistry and Physics 10.2 (2010): 769-775. 